\title{
Geodiversity action plans for the enhancement of geoheritage in the Piemonte region (north-western Italy)
}

\author{
Elena Ferrero*, Marco Giardino, Francesca Lozar, Enrico Giordano, Elena Belluso, Luigi Perotti
}

Università di Torino, Dipartimento di Scienze della Terra, Torino, Italy

\author{
Article history \\ Received December 21, 2011; accepted January 31, 2012. \\ Subject classification: \\ Geodiversity, Geoheritage, Geoethics, Education, Public issues, Geohazards.
}

\begin{abstract}
A geoethical approach to geodiversity allows better understanding of the value of abiotic nature and enhances its conservation and development. Our basic assumption is that even during an economical crisis, geoheritage sites can serve both public and private interests. A set of nine strategic geothematic areas were chosen to represent the geodiversity of the Piemonte region, north-western Italy, each of which is characterized by great potential for scientific studies, enhancement of public understanding of science, recreational activities, and economic support to the local communities. Specialized research teams individuated critical aspects to advance our knowledge of the geological history of the Piemonte region, through climate and environmental changes, natural hazards, soil processes, and georesources. The scientific concepts and techniques were coupled with geodiffusion actions and products: not only geosites, but also museum collections, evidence of mining and quarrying activities, science exhibitions, and nature trails. The preliminary results have allowed action plans to be developed with local partners, to assess the geoheritage management requirements. A series of investigations were carried out to improve the visual representation of the geological processes and the evolutionary scenarios. Further outcomes of the project will include didactic tools for educators, schools, and the public in general.
\end{abstract}

\section{Introduction}

As a general view, geoethics is seen as the set of guidelines that pertain to human behavior that can affect larger planetary geophysical systems, including atmospheric, oceanic, geological, and biological systems [Cascio 2005]. This approach mainly refers to behavior that can result in long-term, widespread and/ or hard-to-reverse changes in global systems; even if transient, local and superficial alterations can be considered through the prism of geoethics. Indeed, other studies have considered geoethics as a new discipline (in both Earth sciences and applied ethics) [Martinez-Frias 2008, Nemec and Nemcova 2011].

Whenever ethical dilemmas occur in problems connected with the sustainable use of the Earth resources, geoethics helps decision makers to undertake scientifically based political decisions [Martinez-Frias 2011]. This view links geoethics to 'geodiversity', which is considered as "the range of rocks, fossils, minerals, landforms and soils that occur on our planet, along with the natural processes that shape the landscape" [Gray 2004]. By developing a geoethical approach to geodiversity, we can understand the value of abiotic nature and devise the correct strategies to conserve a legacy of geological assets. In a few words, we can enhance the 'geoheritage' of a region, i.e. the range of sites or areas of geological features with significant scientific, educational, cultural, or esthetic value [O’Halloran et al. 1994]. Moreover, the geoethical approach helps the potential of geological heritage sites to be identified. These sites might have tourism and economic relevance as local and regional resources [Knudsen et al. 2008], or they might be identified as sites of historical and cultural value that are deserving of conservation (e.g., for the Piemonte region, the Langhian and Serravallian historical Global Stratotype Section and Point) [Mayer-Eymar 1858, Rio et al. 1997].

Knowledge of regional geodiversity is fundamental not only for the successful exploration of natural resources, but also for geohazard assessment and mitigation. Moreover, by developing the correct plans for geodiversity identification and management, a range of social, economic and environmental benefits can be delivered. Enhancement of geodiversity awareness can provide not only the opportunity to study the evidence of past environmental changes and evolutionary processes, but can also reveal information needed for more accurate prediction of future environmental change and for adequate adaptation plans [Giardino and PROGEO-Piemonte Research Team 2011].

\section{Methods and stages of the 'PROGEO-Piemonte' research program}

From a geoethical perspective, the multidisciplinary research project known as 'PROGEO-Piemonte' (PROactive management of the GEOlogical heritage in the 

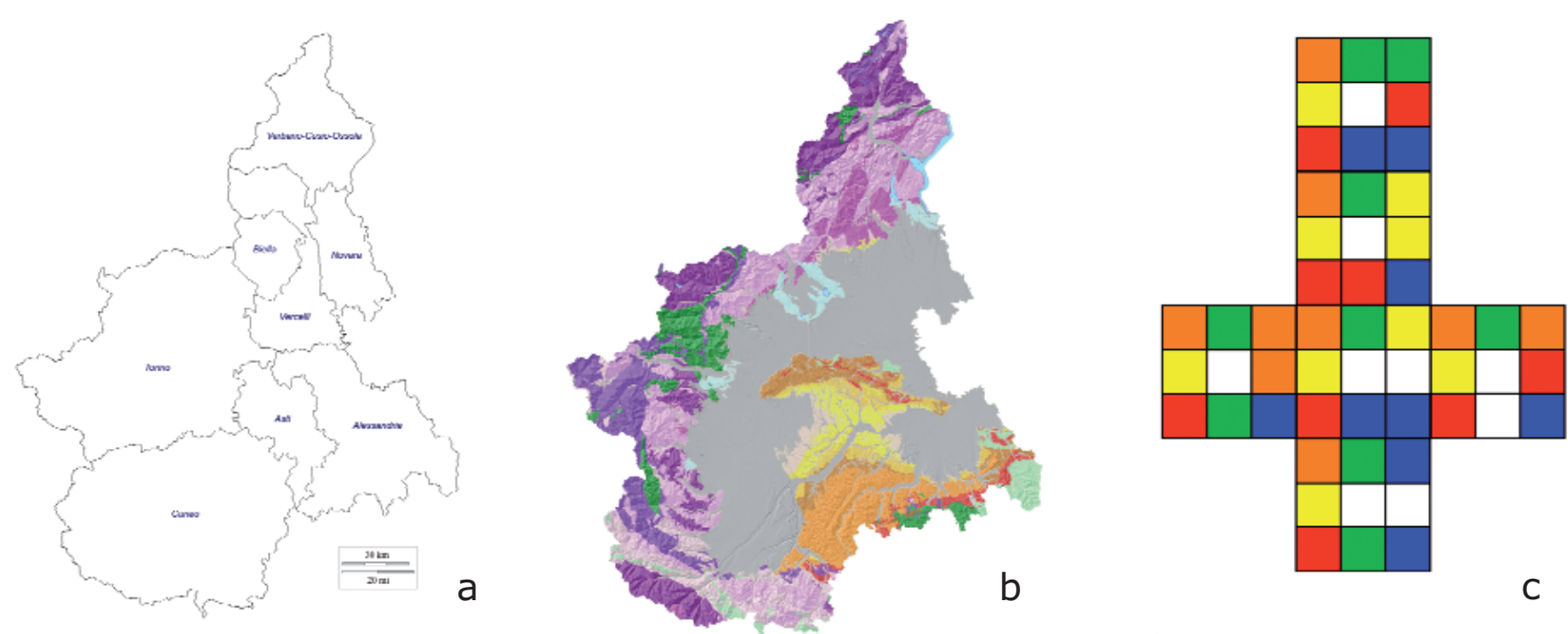

b
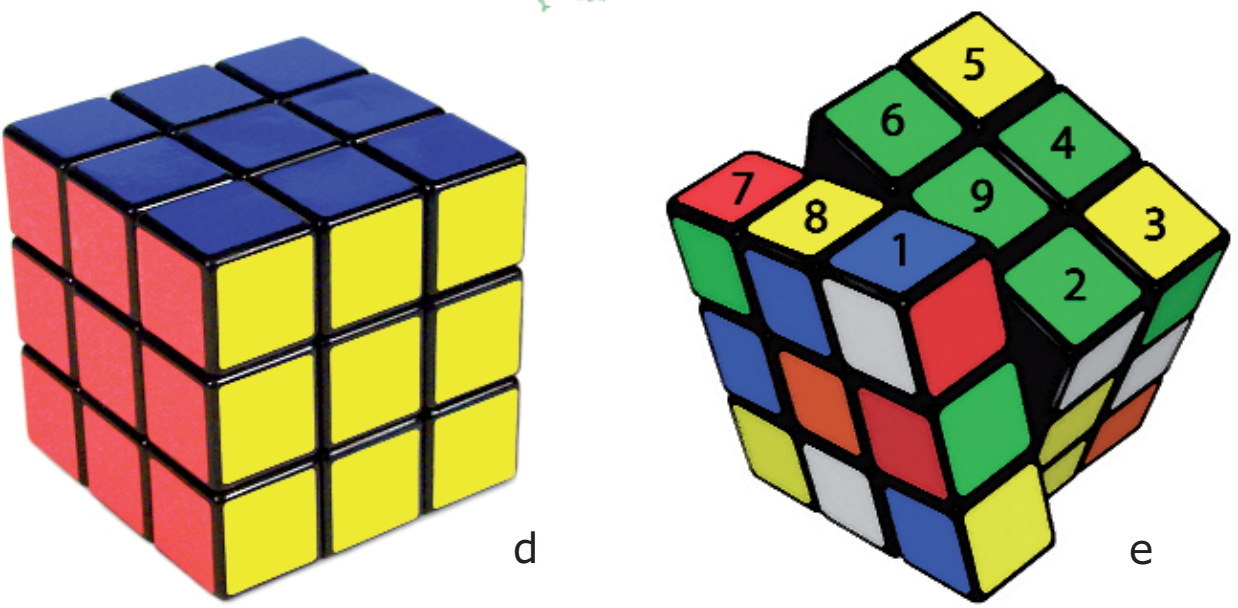

Figure 1. 'Visual' approach of the PROGEO-Piemonte project (see text for description). a. The Piemonte region. b. A representation of the Piemonte regional geodiversity (lithological map by Arpa-Piemonte: http:/ / webgis.arpa.piemonte.it/geoportale/). c. The 'disassembled Rubik cube' analogy. $\mathrm{d}$. The operating selections of the Rubik cube analogy. e. the 're-assembled' Rubik cube of the geological and geographical components of the Piemonte region.

Piemonte region) aims to define a new comprehensive conceptual and operational procedure to promote geodiversity knowledge, assess regional geoheritage, and support geoconservation activities in the Piemonte region (north-western Italy). The scientific background derives from both the geological and geomorphological literature of the area (see below), and from methodological studies relating to the development of techniques for the identification of geodiversity and for the management of geoheritage [Serrano and Ruiz-Flano 1995, Ellis et al. 1996, Erikstad 1999, Wimbledon et al. 1999].

The geoethical management of geoheritage requires a balance to be reached between the protection strategies of georesources and the legitimate needs for fruition by the local population or by visitors. This approach was introduced by the European Working Group for Earth Sciences Conservation that was created on 1988. Then in 1993, this transformed into the PROGEO Association, which is devoted to geodiffusion activities and to establishment of an international network for geosite inventory and conservation [PROGEO 2011]. Following this approach, a 'PRO-
GEO-Piemonte' multidisciplinary research group (Earth sciences, biology, economics, informatics, social sciences, engineering) was created, which involved 58 participants from eight academic research and administrative institutions in the Piemonte region. ${ }^{1}$ Our assumption was that even during economic crisis, geoheritage sites ('geosites') can serve both public and private interests.

The basic principles of geoconservation have been applied in several projects throughout the world. In Italy, we found a gap between the acceptance of this conceptual framework and the application of geodiversity action plans. This is why we consider the application of a balanced mixing of ICT (Information and Communications Technology) instruments and geoethical principles innovative in the recognition of geodiversity, for the promotion of geological knowledge, the preparation of functional guidelines for the management of the geoheritage, and the support of geoconservation activities. The preliminary activities started during 2010. Then, after a long evaluation process by an international committee, the project received financial support from university and regional bank foundations. ${ }^{2}$ 
The main stages of the PROGEO-Piemonte research program are:

(a) Analysis of Piemonte geodiversity at a regional scale, through a comparative study of past and present geological and geomorphological environments.

(b) Identification of 'symbols' for the Piemonte geoheritage, the outstanding scientific and didactic values of which are coupled with the high potential for attracting tourists.

(c) Advanced scientific research on selected geosites and related geothematic areas, to provide a basis for dissemination of regional Earth sciences knowledge.

(d) Experimentation on innovative didactic tools and visual representations of geological processes, and evolution of landscapes, for the enhancement of awareness of the natural resources and hazards.

(e) Promotion of geosites as valuable products, not only as material resources, but also as cultural and geotourism assets that can bring enjoyment to individuals and that are deserving of protection.

(f) Elaboration of strategies for promotion of economic support for local communities responsible for geoheritage management and protection.

\section{Preliminary results on selected geothematic areas}

The application of these methods by specialized research teams from different scientific backgrounds (structural geology, sedimentary geology, paleontology, petrography, mineralogy, physical geography, geomorphology, lichenology, geoscience education) produced a preliminary report on the Piemonte geodiversity at a regional scale. Studies of the geodiversity contents are based on scientific knowledge that was either produced by the participants of this project, or was obtained from the literature. 'Hot topics' for advancing our knowledge on the geological history of Piemonte were analyzed, including climate and environmental change, natural hazards, soil processes, and georesources. As a preliminary result, several geosites were located to symbolize these different themes of Piemonte geodiversity.

A selection then had to be defined, both to enhance the individuality of different provinces of Piemonte (Figure 1a), and for the recognition of new strategic areas to be studied in the region. We applied a visual/conceptual approach to this problem that was based on geographical and geological criteria. Earth scientists used different colors to highlight different geological units. The geothematic map of Figure $1 \mathrm{~b}$ shows the Piemonte regional geodiversity, the analog of which can be individuated in the planar view of a 'disassembled' Rubik cube (Figure 1c). Here, each solid color represents a different geological unit, in term of distinct processes, materials and structural settings. We considered the analogy between this three-dimensional

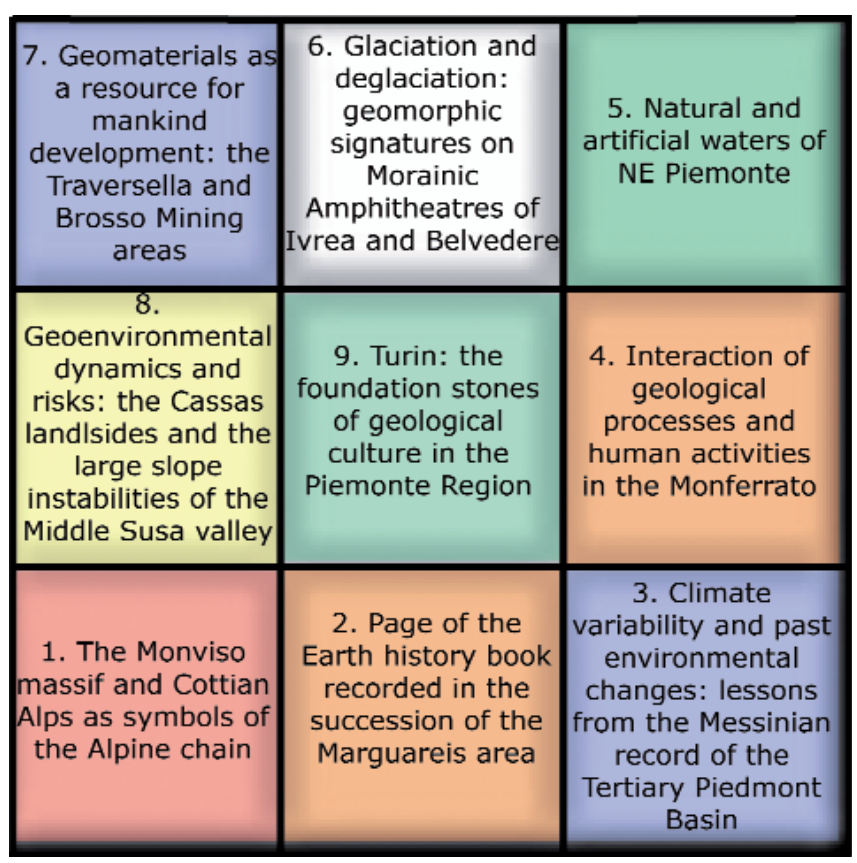

Figure 2. The 'disassembled Rubik cube' analogy for the description of the geothematic areas of the PROGEO-Piemonte project.

mechanical puzzle and an idealized crustal block, with superficial, shallow and deep geoenvironments as a key for operating selections (Figure 1d) and for the 're-assembly' (Figure 1e) of geological and geographical components of the Piemonte region.

This exercise offered different solutions that we evaluated in terms of geothematic contents and geographical distribution. Our choices were addressed to the obtaining of a balanced sample of Piemonte territories, and an (almost) complete representation of its geodiversity. As a result, we identified nine geothematic research themes ('geothemes'; Figure 2, 1 to 9) where we considered the 'symbols' of the Piemonte geoheritage, which was also useful for the enhancement of the cultural awareness of the Earth science topics, and for the promotion of geotourism throughout the region.

Each geotheme represents a distinctive geodiversity feature of the Piemonte region that is deserving of advanced research, and that has particular management and protection needs. Proactive management of these scientific themes (both as diffusion and protection) is now in progress, according to the following four interdisciplinary thematic actions:

(a) Geomatic applications for evaluation and management of Piemonte geoheritage [Ghiraldi et al. 2011].

(b) Visual representation of geological environments and processes.

(c) Geodiversity action plans for dissemination activities.

(d) Tool-integrated management of a geosite: application of a Territorial Integrated Quality Management System (TIQMS).

Our innovative approach to the Piemonte geodiver- 
sity received approval from an international committee, and it is now available to the Regional administration for the assessment and management of the geoheritage. The same visual/conceptual approach is useful to spread awareness of geoheritage among the general public. A better understanding of the complexity of regional geodiversity and its interactions with human activities and territories can promote the correct selection of geosites according to geothematic contents and targeted management activities. This can result in a balanced approach, between geoheritage protection issues and the needs of local populations and of visitors.

The preliminary findings of the PROGEO-Piemonte research groups for both the study of the regional geothemes and in the interdisciplinary thematic actions are analyzed and commented upon in the following sections.

\section{Analysis of symbols of the Piemonte geoheritage}

Piemonte is very rich in geological symbols that can be used to open people's hearts and minds to the magnificence of Nature and to the need for her conservation for the enjoyment of future generations. Here, two examples are presented to provide an understanding of the role of geodiversity in the environmental dynamics of the Piemonte region and of its geoheritage as a cultural asset.

The first example is the Belvedere Glacier (north-eastern face of Mt. Rosa; Figure 2, geothematic area 6; Figure 3), the view of which offers a spectacular analog of the Pleistocene glacial ages, very far from the anthropogenic spread. Here, the most extensive Piemonte glacier has changed its appearance rapidly in the last few years as a consequence of the temperature increases that are affecting the Western

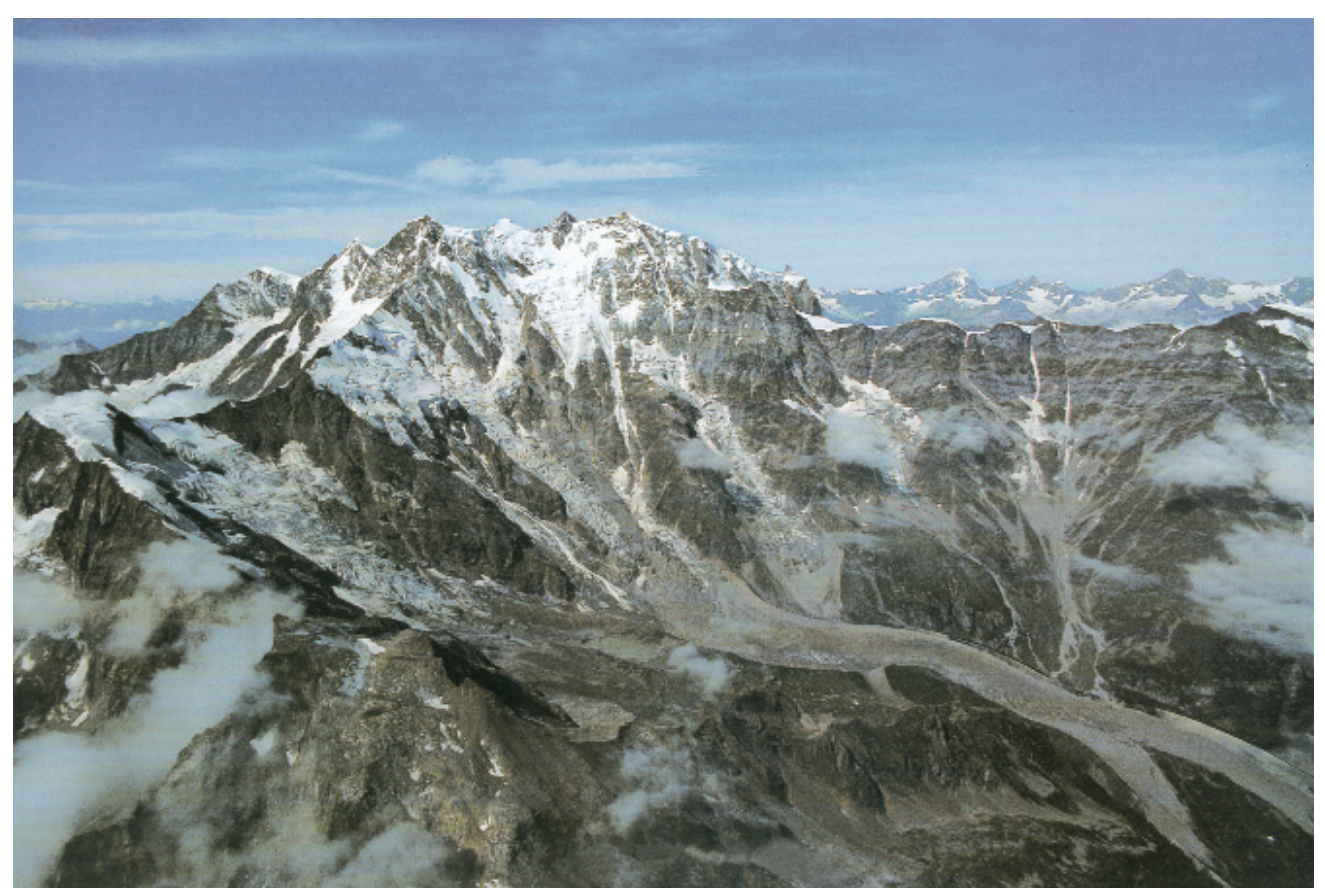

Figure 3. The Belvedere Glacier (photo: Gnemmi).
Alps [Haeberli et al. 2002, Gianotti et al. 2011]. From an educational point of view, the comparison of the present and past geomorphological landscapes allows us to understand the Earth surface processes and these environmental dynamics.

The variations, extent and thickness of the glacier, and its landform changes and mass wasting processes, can be used as lessons to show the effects of climate change and natural hazards [Haeberli et al. 2002]. These can be used to analyze the possible interactions between human activities and the environment. A better understanding of these processes will favor respectful attitudes toward geological assets.

As an example, the putting together of a movie sequence of thousands of images of glaciers that were taken through the temporal window of the last hundred years can provide very convincing evidence of a climatedriven dynamic process for a wider public and will be a useful tool for didactic activities. Moreover, it is a possible tool to widen the consensus on environmental problems, and a way to reach broader adherence and participation in certain choices for the protection of our georesources. Widespread awareness in the general public leads and influences the choices of managers towards the correct management of our georesources.

Another example among the Piemonte geo-symbols is the mining district of Brosso and Traversella (Figure 2, geothematic theme 7) [Costa et al. 2011]. This area has been well known since prehistoric times, when our ancestors began to extract iron, as the 'resistant and strong' material that was useful to produce artisan tools for hunting and working the fields. In ancient times, the local people underwent impositions and abuses by foreign conquerors and local potentates, with pressure to increase the amount of extracted minerals. In more modern times, the mining activities allowed the local people to enjoy greater economic wealth, until the closures of the Brosso and Traversella mines (in 1964 and 1971, respectively). So, the mining trails, the forges spread throughout the area, the extraction tunnels, the mortuary chapels where 'white deaths' were cried over, and the yellow to red sulfur-rich veins all remind us of the hard but fruitful work humans can do. Also, 
the remains of this activity and witnessing the world of the old miners teaches our generation, and future generations, of the need to reduce the human environmental impact and to enhance the safety of the workers.

\section{From scientific knowledge to diffused Geo-awareness}

Geological literacy has a strategic role for the improvement of our awareness of Earth science topics that impact on human affairs. The PROGEO-Piemonte project conceived geothematic themes (Figure 2) to aid in the diffusion of the knowledge of 'hot' Earth science topics, such as:

- Long-term climate change through past geological times (Figure 2, geothematic theme 3), to show its effects on the ecosystem (population and habitat) and geosystem (environmental and landscape changes) [Dela Pierre et al. 2011a, 2011b];

- Time scales of geological processes (stratigraphic and tectonic combined in an orogenic succession) (Figure 2, geothematic theme 2), to reveal long-lasting impacts on our planet, and to show their possible interactions with human activities and on our future [Bertok et al. 2011, d'Atri et al. 2011];

- Limitation of the available georesources (Figure 2, geothematic theme 7) and is influences on the lifestyle of ancient and future generations [Costa et al. 2011].

Up-to-date scientific research on these themes is essential to address the correct management of georesources, and the adaptation for remedial measures for hazardous geological processes.

Accurate dating of paleoclimatic and tectonic events can clarify: (a) how long climate change has lasted in comparison to the human and geological time scales; (b) how these events have impacted on life and the geosystem; and (c) if and when the biome recovered after these events. As an example, new data on this debated topic have been realized through recent studies on the Messinian succession of the Tertiary Piemonte Basin (Figure 2, geothematic theme 3) [Dela Pierre et al. 2011a]. An understanding of the major environmental changes that occurred around 6 million years ago during a short time span (compared to Earth history) is useful, to improve our knowledge of the related modifications to biological communities and the environment.

Improvements in the interpretation of the regional structural settings, stratigraphic and metamorphic characters, and seismo-tectonic activity of the Western Alps (Figure 2, geothematic themes 1 and 2) [d'Atri et al. 2011, Rolfo et al. 2011] are legacies to future generations, because they can help in a better assessment of the georesources and geohazards of the Piemonte mountains. These are other valuable products of the project: they support the idea that geology is an array of ongoing processes that primarily involve the everyday life of our and future generations. Eventually, this newly achieved awareness will strengthen the general idea that continuous Earth science education can improve our life style and our place on Earth [Belluso et al. 2011].

With respect to the educational goals of the project, our strategy is to develop the cognitive aspects of the teaching/learning processes of Earth sciences, while enhancing the sensory and emotional aspects that condition the acquisition of this knowledge [Orion 2007]. Educational materials should create moments of wonder and surprise, including positive feelings related to the moments of discovery. Also, sometimes, they should promote a sense of distress, with the realization of the existence of 'problems' and the personal inadequacy to deal with them [King 2008, p. 197]. All of these sensations and feelings are part of people's emotional intelligence, and they become a powerful stimulus for:

(a) keeping the focus on not-intuitive issues, which are sometimes abstract and rarely explored by direct experience;

(b) motivating personal knowledge improvement, such as looking for visual documents, broadening and deepening the range of interest, repeating the experience in the same place, or in different ones.

According to the suggestions of a holistic approach for science education [Orion 2007], we believe that learning in nonformal educational situations provides an excellent opportunity for the students [King 2008, p. 201]. It makes it easier to perform participatory actions, to produce positive sensations through active personal involvement, with the association of the enjoyment with recreational activities and with feelings of satisfaction for the conquest of a 'goal'.

\section{Geo-resources and geohazards}

Following the International Decade for Natural Disaster Reduction (INDNR 1990-2000), many projects have been carried out on different scales (national, regional, local) to provide better understanding of natural hazards. Then the International Year of Planet Earth (2007-2009) [IYPE 2008, UNESCO 2008] promoted a global view of geoheritage and georesources. In this perspective, our project aims to:

(i) enhance a geo-ethical approach to these fundamental fields;

(ii) increase the competence of local administrators and educators for their understanding of the value of local georesources, and their sustainable exploitation;

(iii) mitigate risks related to hazardous Earth processes.

Three of the geothematic themes of the PROGEOPiemonte project (Figure 2) offer significant enhancements for the awareness of geohazards and geoheritage: 
1) The interactions of geological processes and human activities in the Monferrato Hills (Figure 2, geotheme 4) show that the cultural heritage of this land and the economic value of its worldwide-known vineyard terrain have deep roots on its ancient and recent geological history. Earth sciences knowledge of this area is fundamental for the protection of the local resources from geohazards, and PROGEO-Piemonte promotes the correct assessment and mitigation of local accelerated erosion and slope instabilities [Van den Eeckaut et al. 2010, Masciocco et al. 2011].

2) Studies on the Quaternary evolution of the landscape and the local climates have been used to offer a comprehensive view of the interactions of major geomorphological systems within geothematic theme 5 (Figure 2), where glacial, fluvial and anthropic processes are relevant for local georesources and hazards [Ajassa et al. 2011].

3) As a result of the systematic review of geoscience and natural hazards information, the Middle Susa Valley (Figure 2, geothematic theme 8 ) has become a strategic area for the enhancing of public understanding of natural hazard studies; the achievement of these objectives was made easier by the recreational and didactic activities that are supported by the local communities. Visual representations and digital evolutionary models of large slope instabilities (Cassas landslide and Serre la Voute deep-seated gravitational slope deformation) have popularized scientific results of the recent stages of local geological history, the effects of climate and environmental change and natural hazards, and the related risk management practices in the Susa Valley [Borgogno Mondino et al. 2009, Lombardo et al. 2010, Giardino et al. 2011].

\section{Geosites as cultural and geotourism assets}

Geothemes 1, 3, 4 and 9 of Figure 2 have offered excellent opportunities to illustrate multiple aspects of Earth sciences, due to the variety of geological and geomorphological phenomena they represent. Each of these themes also differs from the others in term of territorial and environmental context: they contain a variety of locations with respect to settlements, infrastructure and manufacturing activities, and different possible accessibility of geosites in relation to the seasonal conditions and the type of public. A coherent and comprehensive selection of geosites makes the geoheritage a valuable cultural resource that can provide local and regional economic benefits as tourist destinations.

As an example, geothematic theme 9 (Figure 2) has been selected, studied and exploited for its very complex and interdisciplinary significance: it emphasized the scientific and cultural value of many historical Piemonte stones [Borghi 2010, Borghi et al. 2011] which have been used in the architecture of the city of Turin, the first capital of Italy

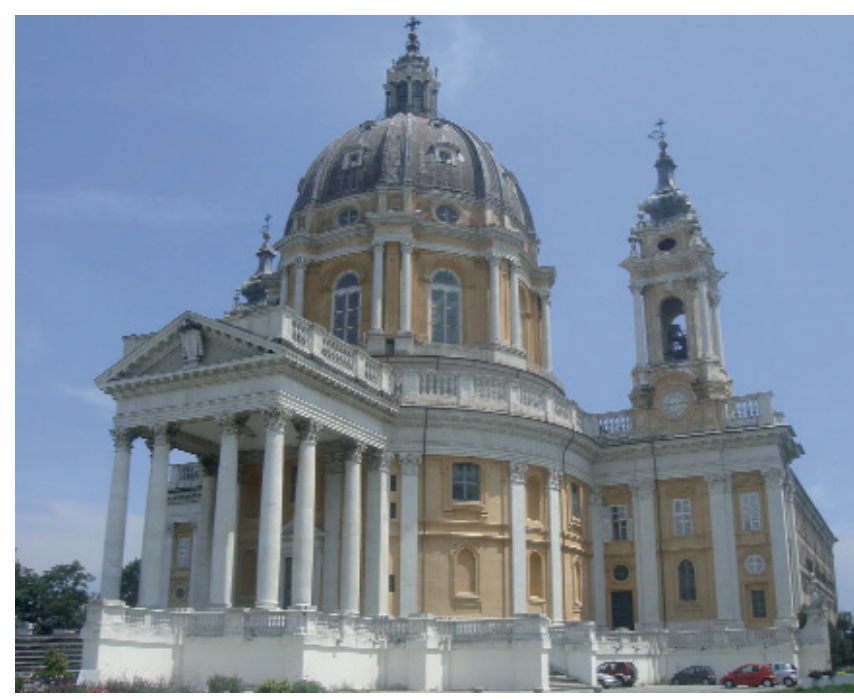

Figure 4. Ornamental stones of Piemonte: the Superga Basilica, via Roma, Turin (photo: Borghi).

(Figure 4) [Favero Longo et al. 2009]. The urban geosites of this geothematic theme are always easily accessible; they offer great potential to promote geotourism, with the integration of historical and artistic aspects of the town with the petrographic nature of the stone used for construction. These geosites are also ideal for educational use by students if they are coupled with visits to the temporary and permanent exhibitions at local museums (e.g. Museo Regionale di Scienze Naturali/Regional Natural Sciences Museum) and with 'virtual tours' that can be offered through the internet (e.g. MuseoTorino) [Lucchesi and Giardino 2011].

\section{Economic support for geoheritage management}

Communities living in a territory with an important geological site should be considered as owners of this property. As a consequence, a program for geoheritage enhancement should have positive local economic impacts. This is a necessary theoretical and practical approach for creating 'virtuous circles' that are aimed at maintaining the site and at raising the geological awareness, both of which are fundamental actions to attain the correct management of territorial assets. The economical benefits derived are then available for an improved quality of life of the resident populations. Administrators should be made aware of the historical, cultural and economical value of geoheritage, so that they can introduce limitations to the exploitation of the site, as geological assets are finite resources. By following the principle of sustainability, these assets will be long lasting, and open to and usable by future generations.

The process that links life quality and sustainability will be analyzed in the PROGEO-Piemonte project by the Commodity Science Department of the University of Turin, by using TIQMS, a certified system that takes into account environmental protection, occupational safety, protection of the landscape, social responsibility and prod- 
uct quality. Using international evaluation standards, TIQMS analyses every step of geoheritage management and development, starting with the involvement of the local community [Beltramo et al. 2011]. Preliminary applications of this methodology have suggested successive steps in the economic development and geoconservation of the geothematic themes; for example:

- in geothematic theme 1 (Figure 2), economic development must take into account the geographical and social contexts. Geologically active areas of the Western Alps are also affected by population loss. Here, the correct evaluation, selection and management of geoheritage sites will boost geo-aware tourism growth, leading to social improvement and geoconservation actions;

- in geothematic theme 4 (Figure 2), the geological and geomorphological assets of the Monferrato Hills are the main constraints for the economic development of the area. A balanced interplay between territorial development and soil conservation policies is suggested, as excess exploitation would lead to the loss of a key resource (vineyards) for the population.

\section{Final remarks and future developments}

By capitalizing on previous successful experiences [Giardino and Mortara 1999, Giardino and Mortara 2004, Boschis and Giardino 2004, Boschis 2010], the PROGEOPiemonte project supports the development of the correct plans for geodiversity identification and geoheritage management of nine geothemes of the Piemonte region (north-western Italy).

A new comprehensive conceptual and operational procedure has been set up:

1) fundamental knowledge of regional geodiversity is achieved by up-to-date scientific research that is addressed to key regional issues of the Earth sciences;

2) management of geoheritage sites is developed with a geoethical approach, which involves local residents and administrators;

3) the correct plans for geoheritage management, to increase the value of the local geodiversity and its sustainable exploitation, is achieved by applying TIQMS.

As one of the main focuses of the project has been on the actions for spreading geological culture, different products have been prepared: teaching materials for primary and secondary schools [King 2008, page 209]; training courses for teachers, restorers, and tourism operators; events for the general public (museum exhibitions, geological field trips); geoheritage promotion through digital media (virtual tours, interactive websites). Other similar products are in progress to further enhance the cognitive aspects of teaching Earth sciences, coupled with sensory and emotional aspects related to the acquisition of knowledge. All of the PROGEO-Piemonte educational materi- als are conceived to be shared with local organizations, schools, and museums.

In addition, the long-term and short-term objectives of the project are integrated into the needs of the local communities, who receive information about the scientific value of the geoheritage of their territory and participate in setting objectives and steps of intervention, to attract visitors and tourism. Local communities and administrators provide human resources and funding for the achieving of the objectives of the project and for the enhancing of the dissemination and use of geological knowledge (e.g. MuseoTorino) [ScopriAlpi 2010, Lucchesi and Giardino 2011].

The development and dissemination of 'geological skills' to children, youths and adults is addressed to a positive impact on the daily life of the local community, both under normal conditions and during geo-hazardous events. Moreover, the PROGEO-Piemonte project promotes healthy and respectful interactions with the physical and biological components of the environment, and with other human communities, by favoring better understanding of the value of geodiversity and stronger perception of the natural risks.

A geoethical approach to the geodiversity of the Piemonte region will reduce local vulnerability to disasters and will support the balanced management of geoheritage through the application of the TIQMS, which is suitable for tourism, sustainable development, and geoconservation.

\section{Notes}

1. Dipartimento di Scienze della Terra, Dipartimento di Scienze della Vita e Biologia dei Sistemi, Dipartimento di Informatica, Dipartimento di Scienze Merceologiche, Università degli studi di Torino; Dipartimento di Ingegneria del Territorio, dell'Ambiente e delle Geotecnologie, Politecnico di Torino; Museo Regionale di Scienze Naturali, Torino; Comitato Glaciologico Italiano; CNR - Istituto di Geoscienze e Georisorse, Torino.

2. Co-financing plan by the Compagnia di San Paolo Bank Foundation and the Università degli Studi di Torino ('Progetti di ricerca d'Ateneo', 2011).

Acknowledgements. The authors wish to thank all the colleagues involved in the PROGEO-Piemonte project and the two anonymous reviewers. Thanks also go to Silvia Peppoloni and Giuseppe Di Capua for inviting us to contribute to this volume and for their accurate editing.

\section{References}

Ajassa, R., E. Destefanis, M.G. Forno, S. Fratianni, F. Gianotti, E. Martinetto, L. Masciocco and L. Perotti (2011). Natural and artificial waters of north-eastern Piedmont (PROGEO-Piemonte project, Geothematic area 5), Epitome, 4, 113, ISSN 1972-1552.

Belluso, E., E. Ferrero, M. Giardino, F. Lozar and L. Perotti (2011). Geodiversity action plans for dissemination ac- 
tivities of PROGEO-Piemonte project (Interdiscipliary research area “C”), Epitome, 4, 278, ISSN 1972-1552.

Beltramo, R., E. Vesce, S. Duglio and M. Giardino (2011). Tool-integrated management of a geosite: application of TIQ (Territorial Integrated Quality) for the PROGEOPiemonte project (Interdiscipliary research area “ $\mathrm{D}$ ”), Epitome, 4, 112, ISSN 1972-1552.

Bertok, C., L. Martire, E. Perotti, A. d'Atri and F. Piana (2011). Middle-Late Jurassic syndepositional tectonics recorded in the Ligurian Brianconnais succession (Marguareis-Mongioie area, Ligurian Alps, NW Italy), Swiss J. Geosci., 104, 237-255.

Borghi, A. (2010). Bacini estrattivi italiani di interesse storico: i materiali lapidei delle Alpi Occidentali, In: Atti della Scuola estiva "I materiali lapidei: tra georisorse e Beni Culturali”. Letture di Georisorse, II, 39-51.

Borghi, A., D. Castelli, E. Costa, A. d'Atri, S. Favero-Longo, S. Ferrando, M. G. Forno, F. Gianotti, C. Groppo, L. Martire, R. Piervittori, F. Rolfo, P. Rossetti and G. Vaggelli (2011). Turin: the foundation stones of geological heritage in the Piemonte region (PROGEOPiemonte project, Geothematic area 9), Epitome, 4, 291, ISSN 1972-1552.

Borgogno Mondino, E., M. Giardino and L. Perotti (2009). A neural network method for analysis of hyperspectral imagery with application to the Cassas landslide (Susa Valley, NW Italy), Geomorphology, 110, 20-27.

Boschis, G., and M. Giardino (eds.) (2004). I monti nati dal mare, Progr. Interreg III.

Boschis, G. (ed.) (2010). Geologia e turismo in Provincia di Cuneo, i Meridiani, 3 vols.

Cascio, J. (2005). Terraforming Earth, Part III: Geoethical Principles, http: / / www.worldchanging.com/archives/ 003189.html.

Costa, E., P. Benna, F. Camara Artigas, G. Dino, M. Fornaro, A. Giuliani, P. Rossetti and M. Rubbo (2011). Geomaterials as a resource for mankind development: the Traversella and Brosso mining areas in the framework of the PROGEO-Piemonte project (Geothematic area 7), Epitome, 4, 132, ISSN 1972-1552.

d'Atri, A., L. Barale, C. Bertok, L. Martire, F. Piana and B. Vigna (2011). Pages of the Earth history book recorded in the successions of the Marguareis area (PROGEOPiemonte project - Geothematica area 2), Epitome, 4, 133, ISSN 1972-1552.

Dela Pierre, F., E. Bernardi, S. Cavagna, P. Clari, R. Gennari A. Irace F. Lozar, S. Lugli V. Manzi M. Natalicchio, M. Roveri and D. Violanti (2011a). The record of the Messinian salinity crisis in the Tertiary Piedmont Basin (NW Italy): The Alba section revisited, Paleogeogr. Paleocl. Paleoecol., 310, 238-255.

Dela Pierre, F., E. Bernardi, S. Cavagna, P. Clari, F. Lozar, E. Martinetto, M. Natalicchio, D. Violanti, P. Benna,
M. Rubbo and E. Zanella (2011b). Climate variability and past environmental changes: lessons from the Messinian record of the Tertiary Piedmont Basin (PROGEO-Piemonte project, Geothematic area 3), Epitome, 4, 134, ISSN 1972-1552.

Ellis, N. V., D.Q. Bowen, S. Campbell, J.L. Knill, A.P. McKirdy, C.D. Prosser, M.A. Vincent and R.C.L. Wilson (1996). An introduction to the geological conservation review, In: Geological Conservation Review n.1, N.V. Ellis (ed.), Joint Nature Conservation Committee, English nature, Scottish nature heritage.

Erikstadt L. (1999). A holistic approach to secure geoconservation in local physical planning, In: Towards the Balanced Management and Conservation of the Geological Heritage in the New Millennium, D. Barettino, M. Vallejo and E. Gallego (eds.), Sociedad Geologica de España, Madrid, 69-72.

Favero-Longo, S.E., A. Borghi, M. Tretiach and M. Piervittori (2009). In-vitro receptivity of carbonate rocks to endolithic lichen-forming aposymbionts, Mycol. Res., 113, 1216-1227, ISSN: 0953-7562; doi:10.1016/j.mycres. 2009.08.006.

Ghiraldi, L., M. Giardino, L. Perotti, P. Cadoppi, G. Balestro and E. Giordano (2011). Geomatic applications for evaluation and management of Piemonte geoheritage (PROGEO-Piemonte, interdisciplinary research area “A”), Epitome, 4, 264, ISSN 1972-1552.

Gianotti, F., M. G. Forno, R. Ajassa, F. Camara Artigas, C. Cigolini, S. Ferrando, M. Giardino, G. Mortara, L. Motta, M. Motta and P. Rossetti (2011). Glaciation and deglaciation: geomorphic signatures on morainic amphitheatres of Ivrea and Belvedere (PROGEOPiemonte project- Geothematica area 6), Epitome, 4, 134, ISSN 1972-1552.

Giardino, M., and G. Mortara (1999). La valorizzazione dei beni geomorfologici: uno studio di geositi nel Parco Nazionale del Gran Paradiso, Riv. Valdôtaine Hist. Nat., 53. ISSM 1120-1371.

Giardino, M., and G. Mortara (eds.) (2004). I geositi nel paesaggio della Provincia di Torino, Prov. Torino, 2 vols.

Giardino, M., M. Bacenetti, L. Perotti, F. Piana, S. Fratianni, R. Piervittori and S.E. Favero Longo (2011). Understanding geoenvironmental dynamics and risks: the Cassas landslide and the large slope instabilities of the middle Susa valley (PROGEO-Piemonte project - Geothematica area 8), Epitome, 4, 55, ISSN 1972-1552.

Giardino, M., and the PROGEO-Piemonte Research Team (2011). PROGEO-Piemonte: a multidisciplinary research project for developing a proactive management of geological heritage in the Piemonte region, Epitome, 4, 132, ISSN 1972-1552.

Gray, M. (2004). Geodiversity: valuing and conserving abiotic nature, Chichester, Wiley. 
Haeberli, W., A. Kääb, F. Paul, M. Chiarle, G. Mortara, A. Mazza, P. Deline and S. Richardson (2002). Surge-type movement at Ghiacciaio del Belvedere and a developing slope instability in the east face of Monte Rosa, Macugnaga, Italian Alps, Norw. J. Geogr., 56, 104-111.

King, C. (2008). Geoscience education: an overview, Studies Sci. Educ., 44, 187-222.

Knudsen, D.C., A.K. Soper and M.M. Metro-Roland (2008). Landscape, Tourism, and Meaning, Ashgate.

Lombardo, V., F. Nunnari, D. Di Giannantonio, J. Landi and R. Damiano (2010). MESH, Mise èn Scene Helper, http:/ / www.edu.vrmmp.it/mesh/.

Lucchesi, S., and M. Giardino (2011). The role of geologists in cultural and human progress, Epitome, 4, 276, ISSN 1972-1552.

Martinez-Frias, J. (2008). Geoethics: proposal of a geosciences-oriented formal definition and future planetary perspectives. TIERRA: Spanish Thematic Network of Earth and Planetary Sciences, http: / / tierra.rediris. es. RedIris. Documentos, 1.

Martinez-Frias, J. (2011). Geosciences: An open-access journal on Earth and planetary sciences and their interdisciplinary approaches, Geosciences, 1, 1-2.

Masciocco, L., R. Ajassa, S. Bonetto, S. Cavagna, C. Cigolini, P. Clari, C. Comina, F. Dela Pierre, E. Destefanis, M.G. Forno, S. Fratianni, M. Gattiglio, F. Lozar, G. Mandrone, L. Martire and F. Piana (2011). Geological processes and their relation with human activities, exemplified in a hilly vineyard area of central Piedmont (PROGEO-Piemonte project, Geothematic area 4), Epitome, 4, 86, ISSN 1972-1552.

Mayer-Eymar, K. (1858). Versuch einer neuen Klassification der Tertiär gebilde Europa's, Verhandl. der Allgemeinen Schweiz. Ges. f. gesammt. Naturwissensch., Trogen, 165-199.

Nemec, V., and L. Nemcova (2011). Developing geoethical infrastructure, http: / / slon.diamo.cz/hpvt/2005/geo etika/ga_1.htm.

O’Halloran, D., C. Green, M. Harley, M. Stanley and J. Knil (eds.) (1994). Geological and Landscape Conservation, Proceedings of the Malvern International Conference 1993, Geological Society, London, UK.

Orion, N. (2007). A holistic approach for science education for all, Eurasia J. Math. Sci. Technol. Educ., 3, 111-118.

ProGEO (2011). Conserving our shared geoheritage - a protocol on geoconservation principles, sustainable site use, management, fieldwork, fossil and mineral collecting, 10 pp; http: / / www.progeo.se/progeo-protocoldefinitions-20110915.pdf.

Rio, D., M.B. Cita, S. Iaccarino, R. Gelati and M. Gnaccolini (1997). Langhian, Serravallian and Tortonian historical stratotypes, In: Miocene Stratigraphy: an Integrated Approach, A. Montanari, G.S. Odin and R. Coccioni (eds.), Devel. Palaeontol. Stratigr., 15, 57-87.

Rolfo, F., P. Cadoppi, G. Balestro, E. Belluso, P. Benna, A. Borghi, F. Camara Artigas, D. Castelli, S. Favero-Longo, S. Ferrando, A. Festa, M. G. Forno, M. Gattiglio, F. Gianotti, M. Giardino, C. Groppo, P. Mosca, R. Piervittori and P. Rossetti (2011). The Monviso Massif and the Cottian Alps as symbols of the Alpine chain in the framework of the PROGEO-Piemonte project (Geothematic area 1), Epitome, 4, 133, ISSN 1972-1552.

ScopriAlpi (2010). ScopriAlpi. Alla scoperta del GeoParco delle Alpi Cozie, brochure; available at http: / www. regione.piemonte.it/museoscienzenaturali/mostre/tem poranee/dwd/Scoprialpi_Pieghevole.pdf.

Serrano, E., and P. Ruiz-Flano (1995). Geodiversity, a theoretical and applied concept, Geographia Elvetica, 62, 140-147.

Van Den Eeckhaut, M., A. Marre and J. Poesen (2010). Comparison of two landslide susceptibility assessments in the Champagne-Ardenne region (France), Geomorphology, 115, 141-155.

Wimbledon, W.A.P., S. Andersen, C.J. Cleal, J.W. Clowie, L. Erikstadt, G.P. Gongrjip, C.E. Johansson, L.O. Karis and V. Suominen (1999). Geological world heritage: geosites, a global site inventory to enable prioritization for conservation. Mem. Descr. Carta Geol. It., 54, 45-60.

\section{Websites}

IYPE (2008). International Year of Planet Earth (2007-2009): http: / / www.yearofplanetearth.org/.

UNESCO (2008). International Year of Planet Earth (20072009): http:/ / portal.unesco.org/science/en/ ev.php-URL _ID=6318\&URL_DO=DO_TOPIC\&URL_SECTION $=201 . h t m l$.

Corresponding author: Elena Ferrero,

Università di Torino, Dipartimento di Scienze della Terra, Torino, Italy; email: elena.ferrero@unito.it.

(C) 2012 by the Istituto Nazionale di Geofisica e Vulcanologia. All rights reserved. 